\title{
Examining the 'Labour' in Labour Migration: Migrant Workers' Informal Work Arrangements and Access to Labour Rights in Urban Sectors
}

\author{
Nivedita Jayaram ${ }^{1} \cdot$ Divya Varma ${ }^{1}$
}

Accepted: 10 September 2020 / Published online: 21 November 2020

(c) Indian Society of Labour Economics 2020

\begin{abstract}
The mass exodus of India's internal migrant workers, from urban areas, back to their villages during the Covid-19 lockdown was met with an outpouring of public empathy. However, policy responses remained restricted to relief, for what was conceived of as a temporary problem precipitated by the lockdown. The migrant workers crisis has been treated solely as an interstate mobility issue, while the lack of wage and employment security or hazardous work conditions, which are commonplace in urban labour markets, does not feature as part of the problem description. This is evident in the attack on workers' rights by state and central governments, through a labour reforms agenda under the garb of economic revival, even at the peak of the migrants' crisis. The article uses pre- and post-Covid evidence on labour rights violations facing migrant workers in three modern, urban work sectors-construction, hotels and manufacturing - spanning the high in-migration cities of Ahmedabad and Surat in Gujarat. It juxtaposes the exploitation of migrant workers with gaps in the country's labour governance architecture, to highlight that suspension of migrant workers' rights is the central feature of urban economic growth, maintained through extra-legal and informal processes in its labour markets. It addresses core tensions and deadlocks in the labour reforms process, to move towards a labour governance architecture that is able to respond to an intersection of challenges presented by informality, mobility and social marginalisation experienced by rural-urban migrants, for enabling inclusive and equitable urban growth.
\end{abstract}

Keywords Migrant workers · Labour legislations · Labour reforms · Urban labour markets · Informality

Divya Varma

divya.varma@aajeevika.org

$1 \quad$ Aajeevika Bureau, Udaipur, India 


\section{Introduction}

The precarity faced by India's migrant workers ${ }^{1}$ in the urban areas where they work was brought to the centre of national attention during the Covid pandemic and resultant nation-wide lockdown from 25th March 2020, leading to widespread public empathy for this otherwise undocumented and invisibilised workforce. Without work or wages, migrant workers were unable to access basic sustenance during the lockdown. As a response, the Ministry of Home Affairs (MHA) issued a circular on 29th March, demanding that employers must pay their wages in full during the period of the lockdown, while an advisory dated 20th March asked establishments to not terminate workers, particularly those employed on contractual or casual basis. ${ }^{2}$ It implicitly recognised access to work and wages as a pre-requisite for the sustenance of workers and their households, and acknowledged the socio-economic value of protecting workers' rights and wages. This order, however, was withdrawn after a Supreme Court ruling on 12th June 2020, that employers and workers must engage in negotiations to settle disputes around work and wages. ${ }^{3}$ Subsequently, State and Central governments have also taken swift steps to dismantle India's otherwise robust labour protective framework, arguing that it is an impediment for Indian businesses. Several states have issued ordinances suspending key provisions for government regulation of labour-capital relations, and the central government has promised expedited action to pass and implement proposed labour codes, which have been critiqued for being pro-employer (Sharma 2020). These are not unanticipated moves, they find their basis in decades' long attempts by successive governments, in the post-liberalisation era, to usher in reforms which assume that the liability of employers to provide for workers has to be weakened for India's economic growth and its competitiveness in the global market (Jenkins 2004).

The policy response of the government to the migrant crisis during the lockdown has been largely limited to announcements on registration, portability through the One Nation One Ration Card and the Affordable Rental Housing Scheme (Koppikar 2020). While these can be potentially useful in addressing vulnerabilities, they have been viewed as an alternative, rather than complementary to labour rights as the employer's liability to workers. At the same time, the dismantling of the labour protective frameworks largely undermines constitutional rights and central labour legislations which protect all workers, including migrants, and regulate their relationships with employers by placing liability on industry to ensure labour standards (Shyam Sundar and Sapkal 2020).

This paper brings forth pre- and post-Covid evidence on labour rights violations facing migrant workers in three urban work sectors-construction, textiles and

\footnotetext{
${ }^{1}$ For the purpose of this paper, migrant workers refer to internal rural-urban migrants who move between states or districts in search of employment and livelihoods.

2 29th March circular: https://dpe.gov.in/sites/default/files/OM_dated_30_3_2020.pdf; and 20th March: https://labour.gov.in/sites/default/files/Central_Government_Update.pdf.

${ }^{3}$ Full text of ruling: https://main.sci.gov.in/supremecourt/2020/10983/10983_2020_36_1502_22526 _Judgement_12-Jun-2020.pdf.
} 
garments, and hotels and dhabas - in high in-migration cities of Ahmedabad and Surat. It focuses on both waged and non-waged migrant workers in these sectors, cutting across caste and gender intersectionalities. Its scope is limited to evidence gathered by Aajeevika Bureau, ${ }^{4}$ through its legal aid work with migrant workers since 2009 complemented with cases reported to its labour helpline and surveys with migrant workers employed in these sectors, conducted during April-May 2020.

The paper maps labour rights violations facing migrant workers against the gaps and inadequacies of labour governance institutions-legislative content, and regulatory bodies responsible for their enforcement such as labour and factories departments, labour courts, and the police, in order to highlight that the migrant crisis during the lockdown was a result of their exclusion from these institutions, forcing them to conduct employment relationships in the extra-legal terrain, governed by adverse norms and practices. It contextualises the migrant crisis within an urban economic model where growth is based largely on the exploitation of migrant workers. It uses this analysis to inform public debate, by highlighting the false dichotomy between responses to the migrant crisis and the labour reforms agenda of the state, which is generated by the logic that economic growth cannot be facilitated without the removal of labour regulations. It concludes by suggesting a policy pathway that facilitates inclusive and equitable economic growth, while attempting to address some of the contentious points in the labour reforms process.

\section{The Paradoxical Question of Migrant Workers' Access to Labour Rights}

Migrant workers' access to labour rights forms a paradoxical question, because labour migration has been identified as the primary means through which industry accumulates profits in the contemporary capitalist economy (Mitra et al. 2017). Jain and Sharma (2018) confirm this by classifying migrant workers as a 'superexploited' workforce, excluded from the entire gamut of labour legislations and oversight of labour regulatory institutions, allowing employers to increase their margins by cutting costs associated with compliance to labour regulations. Their marginal status is created by simultaneous, inter-related processes. On the one hand, migrant workers overlap with the most economically vulnerable and socially marginalised groups in the country (NCEUS 2007), representing rural populations dispossessed from their subsistence-based livelihoods due to the withdrawal of state support to the rural economy in the post-liberalisation period, along with capture of resources by rural elite and corporations (Prasad 2016). At the same time, economic growth in India has been concentrated in large urban agglomerations, through large investments in the services and manufacturing sectors, along with a growing

\footnotetext{
4 Aajeevika Bureau is a not-for-profit organisation based in western India that provides services and solutions to informal and migrant workers. Its legal aid and advocacy work resolves migrant workers' cases through mediation with employers or contractors, activating regulatory institutions, or litigation in labour courts.
} 
construction sector driven by infrastructural development and the real estate boom (Das 2015). Rural-urban migration plays a central role in this urban-led economic growth model, with surplus rural workforce undertaking distress migration to urban areas, as wage-dependent and footloose workers (Breman 2013). Urban sectors prefer employing migrant workers because they are willing to work for adverse terms and conditions, forming a cheap workforce that can be hired and fired at will (Aajeevika Bureau 2020).

Srivastava (2012) argues that temporary migrants do not achieve vertical socioeconomic mobility over the lifetime due to their adverse incorporation into the urban labour market. Sharma et al. (2014) reveal that circular migration occurs early on, at 14-15 years, with workers falling out of workforce when they reach 35-40 years, due to the brutality of long work hours in hazardous conditions, and lack of access to minimum rights required for a healthy life. Jain and Sharma (2018) illustrate that they are abandoned by industry once their utility is exhausted, with the next generation of vulnerable workers taking their place, causing the inter-generational transfer of poverty. The competition created by industry, which utilises migrant workers to undercut local workers, leaves them with the reputation of 'job thieves' (Shyam Sundar and Sapkal 2020) and excluded from social support or platforms for collective bargaining, such as trade unions and local workers' mobilisation (Sharma et al. 2014). Shah and Lerche (2018) point out that circular migration is produced and re-produced by industry as a means to control labour. The lockdown merely aggravated and exposed the routine extraction of migrant workers-employers' impunity to renege on wage payments and responsibility towards workers was fuelled by the state's inability to monitor or prosecute violations, or ensure fair negotiations between employers and workers, which led to negligible compliance towards central government and Supreme Court's orders.

\subsection{Prioritising Interests of Capital Over Labour}

The original intent of India's labour protective framework, far from impeding growth, stresses on balancing the interests of capital and labour to enable industrial peace and enhanced productivity. It provides a minimum floor of rights to workers in order to prevent their undue extraction by capital (Papola and Pais 2007). It operates to de-commoditise labour, viewing workers not merely as a factor of production, but also as citizens whose socio-economic rights must be realised through the protection of their wages and decent work conditions, as well as the right to engage in collective bargaining (Agarwala 2011). The normative basis for protecting labour rights of workers finds its roots in the Indian Constitution which states in Article 43 that the state must ensure work, wages and conditions of work that allow workers a decent standard of life and the full enjoyment of leisure and social and cultural opportunities. This has been upheld through legislations, Supreme Court rulings, the Indian Labour Conferences since 1957, as well as through India's commitment to international human and labour rights standards. Creating a binary between labour rights and economic growth precludes any possibility of equitable and inclusive growth that is not based on suspending the basic rights of workers. 


\subsection{Labour Reforms Without Institutional Reforms}

The liberalisation reforms in India were followed by the emergence of new and nonstandard forms of employment. Such a shift in the nature of livelihoods and employment was not accompanied by a shift in the content of labour legislations or functioning of regulatory institutions. The applicability of legislations is restricted by criteria, such as type of enterprise and nature of employment, which remain rooted in the imagination of formal employment in the organised sector (Thamarajakshi 2005). At the same time, even though various legislations are applicable to unorganised sector workers, labour regulatory institutions are unable to implement these legislations, which are easily evaded by employers and contractors (Chandrasekhar and Ghosh 2002). The importance of institution building for regulating labour-capital relations has been acknowledged by the NCRL (1991), National Commission on Labour (2002) and the NCEUS (2007). Williamson (2002) highlighted institutional reforms with the goal of income redistribution as the natural step following the liberalisation of developing economies, without which 'repeated crisis, low growth, and continuation of high poverty' were inevitable. A reform of labour markets which would entail greater flexibility should not be at the cost of undoing the progress enabled by labour movements, such as a living wage, regulations around dismissals, restriction on working hours or prohibitions of extreme forms of exploitation. Rather, labour market reforms would go hand-in-hand with the protection of workers' rights, investment in human development, social protection, addressing discrimination, supporting small businesses, and progressive taxation structures. Jenkins (2004) argues the reforms process in India has overlooked the strengthening of institutions, with labour policies being formulated by departments responsible for commerce and foreign policy, where priorities are skewed towards cheap production and global competitiveness.

\section{Migrant Workers and Gujarat's Competitive Edge}

Jenkins (2004) argues that changes to India's labour protective framework have been pushed forward through 'stealth', utilising its federal structure. This was evident in the race-to-the-bottom between several states to suspend labour legislations to attract investments. Not surprisingly, Gujarat was one of the first states to suspend labour legislations and weaken labour regulations after the lockdown, following UP and MP. Measures taken by the state for the dilution of labour legislations have long been cited as an example of the rest of the country to follow. ${ }^{5}$ Gujarat's competitiveness is reflected in the FDI into the state doubling between 2019 and 2020, and 734 out of the 2547 large industries set up in India in the past 3 years are in the state (Umarji 2020). Since liberalisation, labour share in gross value has been poor and consistently falling in Gujarat (Sood 2012), while share of wages in net value has fallen at a high rate of $3.25 \%$ annually between 1999 and 2008 (Hirway and Shah

5 See labour reforms introduced by Gujarat here: https://labour.gov.in/gujarat-0. 
2011). At the same time, its per capita income is $20 \%$ higher than national average (Chandrashekar and Ghosh 2014), signalling exclusion and inequality through a combination of low labour costs, repressed wages and significant concessions to industries, which is enabled through high rates of in-migration into its urban areas (Morris 2014).

This paper focuses on three sectors in Ahmedabad and Surat cities, considering the economic powerhouses of Gujarat which rely heavily on migrant workers. In Ahmedabad, informal estimates by Aajeevika Bureau suggest that there are at least 1.3 million migrant workers, forming approximately a 6th of its population, while Surat has been identified as the one of the largest destinations for migrants, who form $58 \%$ of its population (UNESCO 2013, p. 6) and $70 \%$ of all waged workers (Tumbe 2019). This section will focus on the labour practices prevalent in these sectors that enable rampant labour rights violations of migrant workers.

\subsection{Textiles and Garments Sector}

Migration into Gujarat's textiles industry began in the 1960s, before the liberalisation reforms. However, changes in the structure of industry and shift in labour relations have been significant in the post-liberalisation period. Large textile mills in Ahmedabad are now replaced by micro-, small and medium units which perform textiles and garments processing. While medium-sized units are dependent on subcontracted work from larger industrial units or export houses, to perform marginal value added activities such as dyeing, washing, printing and stitching on products that are sold in domestic and global markets by retail brands, micro- and small units rely on further subcontracted orders from mid-sized units for performing very specialised activities for low margins. Most of these units are largely registered under the Gujarat Shops and Establishments Act (SEA), even though mid-sized units employ up to 50 workers, while others are unregistered and unorganised. Surat, on the other hand, became the hub of the informal and unorganised textiles sector, after organised sector mills shut down in Ahmedabad and Bombay following liberalisation. Production of textiles shifted to artisanal and handloom sectors in Surat, which adopted technological and structural changes to accommodate this shift (Breman 1997). Surat's powerloom industry is located in a long value chain, beginning from the yarn factories to powerlooms, dyeing and printing until a downstream segment of sari outlets, producing $40 \%$ of the synthetic fabric in the country, which used to make saris that are sold nationally and overseas (Jain and Sharma 2018).

\subsubsection{Ahmedabad's Textile and Garments Industry}

Extreme forms of exploitation persist in the lowest ends of Ahmedabad's textiles and garments industry, where a large section of women migrants perform homebased work, often engaged by contractors or agents to cut off additional threads from textiles, sew buttons or pockets, and perform embroidery and embellishments or stick rhinestones. They are not recognised as 'workers' under the ambit of labour legislations, while the NSSO classifies them as 'self-employed'. As a result, wage 
violations are widespread in this segment of the workforce. Out of the 50 migrant women home-based workers surveyed, 35 reported that they had not received payments for the orders that were placed prior to the lockdown, for which they had already completed the work. Their contractors had refused to pay them due to the closure of markets and cancellation of orders. Women workers reported such events as common and not restricted to the lockdown-as they do not have legal protection against loss of payments due to demand fluctuations in the market, nature of fast fashion and quality checks. They are paid on a piece rate basis, fetching only Rs. 40 to Rs. 50 per day despite working 10-12 h daily. This payment also includes their cost of production-raw materials, sewing machines, electricity and additional invisible labour of family members including children. They are recruited on the basis of competitiveness and complicity, offering the lowest rates for their labour. OSH or sexual harassment legislations do not recognise the home as a workplace, despite the strenuous nature of their work which causes several ailments. With no labour protection, they form the most flexible workforce that can be shed based on market volatility, without wages or compensations. Due to the Covid-19 lockdown, women reported that they are forced to take whatever orders which fetch them as low as Rs. 10-15 per day despite the same hours of work (Thomas and Jayaram 2020). While local or more settled migrant women also perform home-based work, they are able to access better paying contracts selling finished garments in the local market.

Male migrant workers are hired in micro-, small and medium-sized garments units, but their conditions of work vary significantly based on their caste identity. Migrant workers from OBC and General Caste categories are able to access occupational mobility, invest in their capacities and achieve the status of semisettled or permanent migrants over the years, earning between Rs. 15,000 to Rs. 35,000 per month. Many also become petty contractors or start their own microand small units. However, SC and ST category workers in medium-sized units find themselves restricted to 'helper' level jobs without changes in their wages over the years, earning as low as Rs. 300 per day (Aajeevika Bureau 2020). Despite coming under the ambit of several labour protection laws related to wages, retrenchment or lay-off compensations, welfare benefits, as well as being protected under the Contract Labour and Inter-state Migrant Workmen's Act, almost all the 153 male factory workers surveyed were dismissed without any compensations or support. Even though they are employed in the same units over extended periods of time, performing core activities on a daily basis, they were hired on contractual, daily wage or piece rates outside the permanent rolls of the factory. Even those in mid-sized units reported that non-payment or deduction of wages occurs even in ordinary times, while they are not registered for any welfare benefits including ESIC and PF, and dismissals based on fluctuating demand without compensations or due process are widespread. Over $80 \%$ of the workers had not received wages for work in March, prior to the lockdown. In a case, where the city administration intervened to demand food and wages for the workers, the principal employer refused to provide since they were contractual workers. When the administration approached the petty contractor who had recruited the workers, he resorted to fleeing the city as he could not afford the expenses. Following the lockdown, some workers were recruited to work for 
completing existing orders or to serve in units producing PPE materials. The majority of these workers reported that they were performing work for reduced wages as low as Rs. 150 to Rs. 200, while those who had received some support from their employers or contractors were working to pay off the 'advances'. Women workers are also hired to work on the shop floor but to perform lower paid tasks such as housekeeping, maintaining, folding or packaging products, earning Rs. 50-100 lower than male workers per day. They reported additional gender-based disadvantages as they have not been able to find any jobs post-lockdown.

Both medium and micro- or small units are highly prone to hazards-fires or accidents due to dangerous chemicals and machinery. While marginal employers are unable to invest in better machines or equipped worksites, or compensate workers for their accidents, mid-sized employers refuse to invest in safety and welfare in order to expand their margins. Such units exclusively hire migrant ST families to perform the most hazardous jobs, such as maintaining boilers and cleaning ash from it manually while it runs on high heat. These families sleep next to the boilers with their young children exposed to boiler blasts or burn injuries throughout the day. It is common for migrant workers to live within their worksites, between machines on the shop floor as their low wages restrict them from accessing rented accommodation in the city. They are also encouraged to do so to work longer hours and earn more through the piece rate system. Women workers in particular reported that they face gender-based occupational hazards due to a lack of toilets, rest areas, child care facilities or privacy inside factories where they work and live, and receive no maternity or healthcare benefits. They also face routine sexual harassment which they are unable to report due to the complex procedures involved and the fear of losing employment.

\subsubsection{Powerloom Industry in Surat}

The powerloom industry is one of the biggest employers of migrant workers in the city, with Odiya migrants forming $70 \%$ of its workforce. Coming largely from OBC and SC categories, the workforce is predominantly male, with negligible numbers of women workers. Local Gujarati workers are employed in bigger industries with better margins, including the diamonds industry, which are not accessible to migrant workers (Subramanian 2018). Though the industry is not as fragmented as in the case of Ahmedabad, featuring a homogeneous workforce and easier identification of principal employers, the powerloom industry also operates on a piece rate system, paying workers Rs. 1.10-1.50 per metre of fabric (ibid). With no paid leaves, workers do not know whether they will have a job if they leave for their villages for festivals or marriages. During the lockdown, out of the 296 powerloom workers surveyed, all reported that they were dismissed without wages, and only 26 workers received any support from their employers, which was largely in the form of small of amounts of cash counted as advances. Only one worker attempted to negotiate with the employer, for which he was told that only Rs. 500 would be paid as wages for the entire duration of the lockdown.

Such a payments system pressurises workers to work faster and produce more to be able to earn at least Rs. 7000 to Rs. 12,000 per month, without considering 
its effect on their health and safety (ibid). Often clocking around $12 \mathrm{~h}$ a day in their shifts, more machines are operated per worker in order to expand earnings. This also allows employers to keep labour costs low and reduce the firm size so that they can register themselves under the SEA, rather than the Factories Act. The units are extremely cramped, with workers moving swiftly between several machines, putting them at high risk of occupational accidents, with 84 accidents killing 114 workers between 2012 and $2015,{ }^{6}$ while hearing loss due to the loud noise in the powerlooms effects $95 \%$ of workers. ${ }^{7}$ This is because migrant workers are not allowed to work on better quality machines, but are put to work on cheap locally produced varieties instead. In addition to this, basic facilities do not exist in these looms, forcing workers to walk several blocks in order to access toilets or procure drinking water from chai stalls nearby.

\subsection{Construction Sector}

Ahmedabad and Surat cities are marked by incessant construction activities to facilitate infrastructural development and meet growing demand from the real estate industry that builds modern apartment complexes and office buildings. The construction workforce is drawn from ST workers coming from the adjoining tribal dominated districts of Gujarat, Rajasthan and Madhya Pradesh, who are hired exclusively to perform unskilled or semi-skilled work for very low wages. In Ahmedabad, they are estimated to form $80 \%$ of the total workforce (Prayas 2009, p. 1). While construction sites come under the BoCW Act, they rarely follow its provisions, with $80 \%$ of the 300 medium to large construction sites visited by Aajeevika Bureau over the course of its work not meeting the standards prescribed by the legislation. Out of the 163 migrant construction workers surveyed during the lockdown across Ahmedabad and Surat, nearly half had returned to their villages as they were turned out of their living spaces and worksites as soon as the lockdown was announced, with no support from their contractors or employers. 95\% of contractual construction workers who were stranded in the city reported that they had not been paid for the month of March and had large wage arrears, while most of the daily wage workers had not been paid for the days of work since they returned to the city after Holi in early March.

\subsubsection{Skewed Power Relations Create Adverse Payments Systems}

Construction workers are either hired as daily wage workers (through labour nakas) or contractual labour. Though wages are fixed at about 300-350, wage deductions are frequent, with contractors alleging that they did not complete the work to satisfaction. Contractual workers are hired on the basis of verbal contracts for any period of time between a few days to a few months. They often receive advances before

\footnotetext{
${ }^{6}$ RTI lodged by Aajeevika Bureau in 2018.

7 Medical study conducted by Aajeevika Bureau involving 65 powerloom workers.
} 
they migrate for work, and are given small amounts of cash for their daily expenses. Official record keeping for work and payments is handled by contractors whose records are not available to workers and often do not match their estimates, leaving them with no means to prove the successful completion of their work or discrepancies in payments. Contractors either pay them part of their wages weekly and hold on to the remaining amount, enabling wage frauds. Migrant construction workers lose an average of one month's wages, annually, due to wage frauds.

\subsubsection{Rampant Caste- and Gender-Based Discrimination}

Migrant women are often hired as jodis or couples-not considered as independent workers, but recruited along with their husbands as 1.5 labour units, leading to a large gender wage gap and a lack of control over incomes. They are restricted to the most menial but strenuous activity of lifting and carrying heavy materials throughout the day, yet receiving lower wages. Women over 35 years of age are the last to be hired, often at lower rates as they are considered less fit than younger women. Those who are hired on contractual basis to work on the same site for a period of time report that they are expected to perform additional work well before the beginning of the workday or after the end of worksite activities, including the cleaning of the site and tools, maintaining materials or fetching tea, all gender-based work for which they do not receive additional payment. They report 9-10 h of work daily. Women often work until they deliver their infants on the site which has no basic facilities, or return to work within 15 days of their delivery with their infants in tow. They receive no maternity benefits or ante- and post-natal care (Jayaram et al. 2019).

\subsubsection{Unsafe Worksites and Lack of Access to Housing}

India's construction sector is considered the most dangerous sector, accounting for the highest proportion of occupational accidents in the world, leading to a high number of labour fatalities and disabilities (Kulkarni 2007). Migrant workers are left with no income source following their accidents. Despite BoCW safety regulations and provisions for post-accident compensation, migrant workers are unable to access even proper medical treatment through their employers and are forced to return to their villages. The accidents are rarely reported even after repeated occurrences at the same site, in spite of the requirement to report workplace accidents within $48 \mathrm{~h}$. Due to the absence of child care facilities, children frequently roam the hazardous sites without supervision and are exposed to the same hazards (Jayaram et al. 2019).

The lack of a living wage forces ST family migrants to live either on site or in open spaces across the city. In the first case, they are not provided onsite housing in accordance with the BoCW, but are forced to live in auto-constructed labour colonies, which are made from scrap material on the site, with no other facilities available. Many ST migrant families therefore prefer to work on a daily wage basis, which leaves them to undertake the arduous process of finding work at the nakas daily. They are often unable to find more than 15-20 days of work in a month, facing high employment and wage insecurity, due to which they cannot afford rented housing. They resort to living on pavements, empty lots, near railway tracks or under 
flyovers - where they are considered illegal inhabitants by the city administration and police. Single male migrants, on the other, live in informal and highly unhygienic rental rooms, where 15-20 workers share a space of 8 X10 feet. In all these cases, access to water, sanitation, healthcare or nutrition is compromised (Aajeevika Bureau 2020).

\subsection{Hotels and Dhabas}

Ahmedabad's hotels and dhabas sector is dominated by medium- to small-sized units, which are labour intensive, involving long work hours and difficult work. These jobs, including cooks, helpers, cleaners and waiters, exclusively draw from the migrant workforce, while local labour are hired in supervisory positions such as cashiers or managers. Jain and Sharma (2018) reveal that within the migrant workforce from Rajasthan employed in Ahmedabad's hotels, only 2\% are able to access supervisory positions, of which $90 \%$ are from the General Caste category. Migrant workers who are hired as cooks and waiters are also from General Caste category, dominated by Brahmins due to notions of purity associated with food. Even though ST migrants form approximately half of the migrant workforce in this sector, they are restricted to the position of helpers, earning only about $65 \%$ of the wages of those in higher positions. These extractive labour practices are further enabled by the poor enforcement of the Gujarat SEA under which hotels and dhabas are registered.

All of the 32 hotel workers that were surveyed reported that they were forced to set out on foot as soon as the lockdown began because their hotels (also their living spaces) were shut down and they were immediately dismissed from the worksite with large wage arrears. While most of them attempted to hold their contractors accountable, the contractors reported that they were unable to recover wages from hotel employers who refused to pay them.

\subsubsection{Deceptive Recruitment and Payments Systems}

ST workers are often hired with the promise of free food and accommodation, but soon find out that they are paid lower wages because of this provision, leading to wage cuts of Rs. 3000 to Rs. 3500 on an average (Aajeevika Bureau 2020). Employers require them to stay on premises so that they can be called into work early and will be available late into the night, leading to long work hours well beyond statutory limits with no overtime payments. The facilities that they are provided are often cramped rooms or open halls of the restaurant where 15-20 workers sleep on the floor. In many hotels, workers are forced to eat poor-quality, leftover food. Employers deploy tactics akin to bondage of preventing workers, especially those under age from going home, or paying partial wages for work completed before workers go to their villages temporarily to ensure that they will return in order to retrieve the wages. Only workers who can access better positions based on their caste identity, earning around Rs. 15,000 or above, are able to live in rental accommodation. 


\section{Employers' Impunity Fuelled by Gaps in Labour Governance Architecture}

The common factor between diverse extractive labour practices in the sectors described above is that the relationship between migrant workers and their employers or contractors remains in the extra-legal territory. Their inability to invoke employers' liability to provide for them as a statutory right leaves them with work relationships that are not legally regulated, but based on social identities of caste, gender and ethno-linguistic identity. They are forced to refrain from demanding better conditions as their complicity is required to maintain relationships that provide access to employment. The labour governance architecture, however, does not recognise or respond to the complex intersection of informality, mobility and casteor gender-based discrimination that enables violations of migrant workers' labour rights.

Often, this is due to the limitations in legislations, which are not inclusive of the large section of unwaged populations who fall completely outside their scope, such as home-based workers. However, even in the case of waged workers, these legislations remain unenforced. In the textiles and garments sector, for instance, employers split their production activities across different units to avoid registration under the Factories Act, coming under the ambit of the SEA instead. They also avoid firm level registration of workers, often creating dummy records with fake names or identities that do not reflect the real size of the firm. Even in units where welfare provisions such as PF are applicable, employers often cut PF payments but do not make it accessible to workers. The enforcement mechanism is, however, unable to monitor firm level registration of workers or the actual scale of operation of these units in order to bring these worksites under the purview of applicable legislations. Despite limitations in legislations or the inability of enforcement mechanisms to bring worksites under their purview, there are a large number of laws that regulate informal labour relations, even in the unorganised sector. This is contrary to the widespread notion that labour legislations are not applicable to informal workers. This includes all wage legislations, as well as the Employee's Compensation Act (ECA), the Contract Labour Act, ISMW Act and BoCW Act. In addition to this, the Bonded Labour Act and the Child Labour Act place criminal liability on employers for violations. However, migrant workers find it difficult to access legal protection for a variety of reasons, described in this section.

\subsection{Unwilling to Respond to Informality}

Employers rely on obscuring employment relations so that they cannot be held accountable in the case of labour violations. In all sectors, employers not only keep workers off the books, but also ensure that they do not receive payslips or other records of employment. In addition to the lack of formal documentation, the use of long contracting chains with multiple levels of intermediaries, such that workers often do not know the identity of the principal employer or name of the worksite, is common. In Ahmedabad's construction sector, seven levels of intermediaries were 
reported between workers and the principal employer, where they only have contact with the petty contractor at the lowest level. Contractors do not provide them their full names or contact details and resort to fleeing when they are unable to pay workers. Even though the Contract Labour Act and the Payment of Wages Act hold principal employers liable for wage payment when the contractor does not do so, workers are unable to access this provision. One-way record keeping by the contractor means that workers have no control over formal records of the work performed by them, which is unilaterally decided by the contractor. Daily wage workers or those based on short-term oral contracts have multiple principal employers or contractors, none of whom bear the responsibility for provisioning for workers as they are counted as temporary labour. While the ISMW Act protects migrant workers by mandating contractors to register with the state, it remains on paper alone. Furthermore, the ISMW Act pins responsibility on the contractor, without providing for workers to be registered with the principal employer in order to prove employment relations. It also does not account for intra-state migrants or petty contractors who often do not recruit more than 50 workers at a time.

In the case of civil violations, Labour Departments and Labour Courts offer both mediation and litigation processes, respectively, but require formal documentation. Mediation processes through Lok Adalats bring both contractors, principal employers and workers to the table, but it does not have means to identify or mandate contractors or employers to engage in the process. As a result, it has proven more effective in the case of principal employers in the organised sector, who are more easily identifiable. The mediation mechanism is undertaken by officials who do not understand adverse norms and practices in the informal sector and is therefore biased against the workers who do not have formal documentation. The litigation process through labour courts, on the other hand, is both time consuming and expensive. Lawyers also often declare workers' case unviable due to their small ticket size and lack of documentation, as they are not trained in measures to compensate for the lack of formal proof in the informal sector. With respect to the ECA, even after a favourable ruling, the burden of proof of the employer's ability to pay the compensation rests on the worker before the recovery of claims. Unlike other courts, labour courts cannot initiate follow-up processes to ensure that its orders have been implemented by employers, leaving workers to undertake complex processes to claim their rights.

\subsection{Lack of Recognition of Mobility-, Caste- and Gender-Based Discrimination}

Migrant workers' heavy dependency on the contractor, along with the casteand gender-based power dynamics, dissuades them from approaching the state machinery for complaints. While police stations are more visible and have last mile presence, migrant workers reported that they were afraid of the police, with employers and contractors threatening to report them on the basis of false charges. Those who had approached police stations or labour department despite this report that they face suspicion on the basis of their migrant status, as well as caste- or gender-based discrimination when reporting cases. Police stations only respond to cases of criminal violations and are quick to dismiss other labour 
violations, without realising that abuse, threats and harassment are also aspects of the same cases. While the SC/ST Atrocities Act and Sexual Harassment of Women at the Workplace Act protect against caste- and gender-based violence, they are not integrated into the labour protective mechanism, which does not recognise the effects of social segmentation in the informal labour markets.

In the case of criminal offences under bonded labour cases, activating a response to criminal complaints by the police was reported to be especially difficult because of non-cooperation and complicity of the police with employers, as well as inability of the worker to pursue the case as they are forced to return to their villages.

\section{Steady Weakening of Labour Regulatory Mechanisms}

The labour governance architecture is severely under-resourced and understaffed. The total budget allocated to the Labour Ministry only marginally increased in 2020-2021 compared to the previous year. There were no allocations under Industrial Relations (schemes for strengthening the adjudication machinery, organising Lok Adalats, creating mechanisms for better conciliation of disputes, prevention of violations through mediations and effective enforcement of labour legislations) and Working Conditions and Safety (which have provisions for improving infrastructures in docks, mines and factories). These two functions received only Rs 34.9 crores each in 2019-2020. Major deductions in allocations for SC, ST and OBC and child labour were also a feature of the budget. The Parliamentary Standing Committee on Labour reported that more than $20 \%$ of allocations to the Labour Ministry was unutilised in 2019-2020. This is not surprising, since inspections rates in the country have been steadily falling, with the number of inspections carried out having decreased between 2017-2018 and 2018-2019 to 3670 inspections, while the number of convictions has decreased almost by half in the same period, falling as low as 2433 in 2018-19.

At the Directorate General Factory Advice Service and Labour Institute (DGFASLI), only 218 out of 372 sanctioned posts were filled. The under-resourcing of a significant department for labour protection is accompanied by an expansion in funding for the Ministry of Commerce and Industry, with the Make in India allocations to incentivize industrial growth increased by nine times between 2018-2019 and 2019-2020. Budgetary allocations for labour in Gujarat have declined, in comparison with other industrialised states such as Tamil Nadu and Karnataka, while only $58 \%$ of all sanctioned posts for monitoring compliance to the Factories Act 1948 were filled in 2011 (Shyam Sundar 2014). Such a lack of resourcing and staffing also has a direct impact on the accessibility of labour enforcement mechanismsall workers surveyed did not know of the existence of a labour department where they could report their complaints. The labour department is absent in migrant hotspots of these cities, which are usually in peripheral or industrial locations, and does not perform outreach activities such as the legal awareness building or support with complex bureaucratic procedures required for registering grievances. 


\section{Examining Arguments for Dismantling the Labour Protective Framework}

The further weakening of the labour governance architecture has been viewed as a pre-requisite for economic revival post-Covid. This has been based on two arguments. First, it is necessary for attracting investments to the country. However, it appears that India's hopes of attracting global supply chains moving out of China might have been belied with a lot of them anchoring themselves in smaller countries such as Vietnam (Dutta 2020). Narratives from owners and representatives of global businesses suggest that parameters such as availability of robust infrastructure, reliable and cheap power supply, road networks, tariff regimes and ease of logistics are critical factors that drive decisions on investment destinations and India may have lost out on account of significant deficits on these dimensions, despite efforts to signal 'ease of business' to global supply chains through relaxation of labour laws (Jacob 2020). While labour cost is most certainly an important parameter of decision making, the fact that a vast majority of employment in global supply chains in India is fragmented and hence in the informal realm anyway means that from the vantage point of investment decisions, there is not much to be optimised by way of labour costs even if significant relaxations are introduced.

A second significant argument has been that labour legislations will prevent MSMEs, which cannot bear the costs of compliance, from recovering or growing the post-pandemic phase. However, 20 employers in textiles and garments MSMEs across Ahmedabad's textiles and garments sector and Surat's powerloom industry reported that labour laws are the least of their concerns. Rather, their major concern is the lack of demand within domestic markets fuelled by the falling wage and employment security in the country. In addition to this, they cited the high costs of other factors of production, such as electricity, rent, and transportation, which was inhibiting them from restarting their businesses, because they could not bear their fixed working costs in the face of a decline in orders. Marginal employers also argued that severe indebtedness from government policies such as demonetisation and GST badly hit their businesses, due to which they would not be able to access or service more loans.

A deeper examination of conditions in other Asian countries suggests that their competitiveness is on account of their high performance on several dimensions outlined above. For instance, countries such as Vietnam have been able to achieve a sensible balance between availability of skilled manpower as well as ease of doing business through investment in education and the creation of strong public infrastructure Agrahari 2020). Vietnam has also instituted certain progressive measures in terms of labour protection through introducing stipulations for definite-term labour contracts which prohibits employers from hiring workers endlessly on a seasonal or casual basis (Landau et al. 2015); recent amendments to Vietnam's Social Insurance Law now extends compulsory social insurance to such workers (Vietnam Law and Legal Forum 2015). On similar lines, China, which still holds the biggest share of investments from global supply chains, 
ensures stricter labour protection and better social security provisioning than India (Jacob 2020). According to Sood and Nath (2020), China's minimum wage regulations mandate wages that are three times the rates in India. Reports indicate that having fair labour practices also augments their amenability to inspections and audits that have emerged as a highly common demand by North American and European buyers (Dutta 2020). All of this evidence read together indicates that rather being a real bottleneck to garnering fresh investments, 'rigid' labour laws in India are most often, just a myth propagated to justify the labour reforms process.

\section{Labour Reforms Towards Equitable Growth and Industrial Peace}

In spite of its low importance in attracting investments or helping MSMEs recover, why has the labour reforms process ${ }^{8}$ been the most significant post-Covid policy announcement by both regional and state governments? Industry associations such as FICCI, CII and ASSOCHAM have applauded governments for undertaking reforms, since it benefits large industrialists who engage organised workforce in their factories, where workers' collective bargaining and the state's regulatory mechanisms to hold principal employers liable hold greater potential. The removal of the labour protective framework would lead to the informalisation of the small fraction of organised workforce in the country, rather than encourage unorganised units to formalise (Shyam Sundar and Sapkal 2020).

\subsection{Addressing the Vulnerabilities of Marginal Employers}

The labour reforms processes have turned a deaf ear not only to the concerns of workers' representatives, but also to those of MSMEs who produce for large buyers and retailers within supply chains, while employing migrant workers in large numbers (Economic Times 2020). The nature of the supply chains in which they are engaged is based on high levels of competition and a race-to-the-bottom in order to capture orders from larger players who do not provide enough margins to allow labour protection. However, the labour reforms narrative does not feature this perspective, or recognise the responsibility of bigger players in the industry, while blaming labour legislations alone for the challenges facing MSMEs. The labour reforms process must work towards ensuring the redistribution of income across supply chains, with the definition of principal employer re-conceptualised to include buyers and retailers at the top of supply chains. Their liability must be invoked through processes to bring greater transparency in supply chains, which holds them accountable for minimum labour standards at all units supplying to them by formalising contractual relations across the supply chain until the last worker. A graded

\footnotetext{
8 The labour reforms process, here, refers to both moves by regional governments to suspend labour legislations, as well as the draft Labour Codes by the central government, that are in various stages of drafting or enactment.
} 
system for compliance may be introduced with all units maintaining a basic floor of employment standards and ensuring better standards progressively, based on turnover or numbers of workers employed.

Micro-enterprises that employ vulnerable migrant workers in large numbers must be de-clustered from small and medium enterprises and fiscal stimulus by the state must be ensured in order to revive demand and ensure their sustainability. Providing state support to subsidise rent, electricity costs through affordable credit would be a useful start, also from the point of view of bringing them into the ambit of legality. Promoting industrial clusters with a view to ensure economies of scale through reducing costs of logistics, transportation and fuel would also be useful long-term measures to enhance sustainability.

\subsection{Fixing Principal Employer Liability}

The labour reforms agenda, rather than bringing big buyers and industrialists to account, has persistently undermined the ability to prosecute principal employers. The labour codes have changed the definition of principal employer to include even contractors or site managers, shifting greater liability onto the latter. While the nonpayment of wages was a criminal offence, considered at par with forced labour, the labour codes now make it possible for employers to deduct wages through myriad ways (Jayaram 2019).

The labour reforms process must initiate the comprehensive identification, recognition and inclusion of the entire spectrum of non-standard employment (including home-based work, piece-rated work and family-based labour) into the ambit of the formal legal-policy ecosystem. Registration of workers in sectoral boards can be a useful first step in this process. This can be further strengthened by ensuring the registration of firms and enabling registration of workers as employees of specific firms so that a direct identification and establishment of employment relationship is possible.

\subsection{Addressing Labour Market Segmentation}

The labour governance architecture is not mindful of the centrality of caste- and gender-based segmentation of labour markets as the operating logic of modern work sectors, with migration forming an additional layer of vulnerability. Rather than introducing legislations to tackle this process of labour extraction, it has further reduced women's access to equality of opportunity in recruitments, promotions and transfers by eliminating the provision in the Equal Remuneration Act. Labour legislations must have strong provisions for countering discrimination based on social identity to prevent the ghettoisation of seasonal and circular migrants in forms of work that do not allow any socio-economic mobility. Anti-caste and gender discrimination laws such as the Sexual Harassment of Women at the Workplace and the SC/ ST Atrocities Act must be integrated into the labour protection framework through the codification process. In addition to this, labour regulatory mechanisms from police stations to labour departments and courts must be sensitised to caste- and 
gender-based discrimination, while frontline officials must be held strictly accountable for discriminatory behaviour towards marginalised groups. The challenges posed by the mobility of workers, in terms of registration, follow-up and resolution of cases across source and destination regions must also be addressed.

\subsection{Strengthening of Labour Protective Institutions}

The labour reforms process has responded to the critique of the 'Inspector Raj' by further weakening the labour regulatory mechanisms through introducing self-certification for compliance and restricting inspections to a centrally managed system, which leaves no scope for inspectors to respond to complaints received. Rather than relaxing employer compliances simplification should be done through designing and enabling a single integrated mechanism for different compliances and registrations. Corruption in the labour regulatory institutions can be countered with systems for greater accountability, such as top-down monitoring of inspections and reporting. In addition to this, greater worker and civil society participation in the inspections process in order to check the corrupt tendencies of labour inspectors would be important. Workers' organisations and unions, as well as civil society partners, must be empowered to report grievances and initiate the inspections processes in firms and industrial clusters where violations are taking place, and be allowed to perform social audits as well as accompany labour inspectors during the inspections process. Trade unions have historically been viewed as a central component of industrial peace by ensuring that production processes are not disrupted due to the unresolved disputes and labour market anarchy. Opportunities must be created for informal and migrant workers to register their own unions or ensure their participation in recognised unions through affirmative action.

\section{Conclusion}

The migrant crisis during the Covid-19 pandemic and lockdown provides a unique opportunity to re-conceptualise India's labour reforms process. However, the opportunity has been thwarted by the binary created between economic growth and labour rights, strengthened by regional and central governments' policy responses for dismantling the labour protective framework, to further enable an economic model that bases itself on the extraction of vulnerable migrant workers, such that they are unable to access a basic or minimum floor of labour standards. Such an agenda will damage any possibility for addressing the core tensions in the labour reforms process in a productive manner, such that India's economic model is not merely based on cheap and flexible migrant labour, but an inclusive and equitable growth with industrial peace and productivity as its central factors. Public empathy towards the conditions facing migrant workers must be able to identify the migrant crisis as a direct result of the complete absence of labour governance architecture in the segments of the urban labour markets that employ them, fuelling impunity of employers to perpetuate extractive labour practices. The labour reforms process must bring the 
protection of migrant workers to the centre of its agenda by strengthening institutional mechanisms for holding employers liable for violations of their labour rights.

Acknowledgements The authors express their thanks to Vikas Kumar for his critical support in evidence collection, as well as Aajeevika Bureau's Legal Education, Aid and Advocacy (LEAD), Ahmedabad and Surat teams, for their important insights.

\section{References}

[UNESCO] United Nations Educational, Scientific and Cultural Organization. 2013. Social Inclusion of Internal Migrants in India. New Delhi: UNESCO.

Aajeevika Bureau. 2020. Unlocking the Urban: Reimagining Migrant Lives in Cities Post Covid. Udaipur: Aajeevika Bureau.

Agarwala, Rina. 2011. Using Legal Empowerment for Labour Rights in India. The Journal of Development Studies 55(3): 401-419.

Agrahari, Amit. 2020. As Companies Flee China, Vietnam is Taking Away the Cake India So Desperately Wishes to Have. TFI Post, 25 April. https://tfipost.com/2020/04/as-companies-flee-china -vietnam-is-taking-away-the-cake-india-so-desperately-wishes-to-have/. Accessed 11 Aug 2020.

Breman, Jan. 1997. Footloose Labour. Working in India's Informal Economy. New Delhi: Cambridge University Press.

Breman, Jan. 2013. At Work in the Informal Economy of India. New Delhi: Oxford University Press.

Chandrasekhar, C.P., and Jayati Ghosh. 2002. The Market that Failed: A Decade of Neoliberal Economic Reforms in India. New Delhi: Leftword.

Chandrashekar, C. P. and Jayati Ghosh. 2014. Have Workers in Gujarat Benefited from "Development". Business Line, 12 March. https://www.thehindubusinessline.com/opinion/columns/cp-chandrasekhar/have-workers-in-gujarat-benefited-from-development/article20743934.ece. Accessed 11 Aug 2020.

Das, Raju. 2015. Critical Observations on Neoliberalism and India's New Economic Policy. Journal of Contemporary Asia 45(4): 715-726.

Dutta, Prabhash. 2020. Covid Spillover: Firms Shifting from China to Vietnam has a Lesson for India. India Today, 10 June. https://www.indiatoday.in/business/story/covid-spillover-firms-shiftingfrom-china-to-vietnam-has-lesson-for-india-1687344-2020-06-10. Accessed 11 Aug 2020.

Economic Times. 2020. MSMEs to be Classified Based on New Criteria from July. Economic Times, 5 June. https://economictimes.indiatimes.com/small-biz/sme-sector/msmes-to-be-classified-based -on-new-criteria-from-july/articleshow/76175735.cms\#: :text=NEW\%20DELHI\%3A\%20Fro m\%20July\%2C\%20over,the\%20'medium'\%20enterprise\%20category. Accessed 11 Aug 2020.

Hirway, Indira, and Neha Shah. 2011. Labour and Employment Under Globalisation: The Case of Gujarat. Economic and Political Weekly 46(22): 57-65.

Jacob, Rahul. 2020. India is Chasing an Elusive China Dream. Livemint, 21 May. https://www.livem int.com/news/india/india-is-chasing-an-elusive-china-dream-11589988309466.html. Accessed 11 Aug 2020.

Jain, Priyanka, and Amrita Sharma. 2018. Seasonal Migration of Adivasis from Southern Rajasthan: A Political Economy View of Labour Mobility. Journal of Interdisciplinary Economics 31(1): 63-99.

Jayaram, Nivedita. 2019. Protection of Workers' Wages in India: An Analysis of the Labour Code on Wages 2019. Economic and Political Weekly 54(49).

Jayaram, Nivedita, Priyanka Jain, and Sangeeth Sugathan. 2019. No City for Migrant Women: Construction Workers' Experiences of Exclusion from Urban Governance and Discrimination in Labour Markets in Ahmedabad. Gender \& Development 27(1): 85-104.

Jenkins, Rob. 2004. Labor Policy and the Second Generation of Economic Reform in India. India Review 3(4): 333-363.

Koppikar, Smruti. 2020. Affordable Housing for Migrants is a Band-Aid, a Salve for Middle India's Conscience. Moneycontrol, 18 May. https:/www.moneycontrol.com/news/business/markets/affor 
dable-housing-for-migrants-is-a-band-aid-a-salve-for-middle-indias-conscience-5281391.html. Accessed 11 Aug 2020.

Kulkarni, G.K. 2007. Construction Industry: More Needs to be Done. Indian Journal of Occupational and Environmental Medicine 11(1): 1-2.

Landau, Ingrid, Petra Mahy, and Richard Mitchell. 2015. The regulation of non-standard forms of employment in India, Indonesia and Vietnam. Conditions of Work and Employment Series No. 63. Geneva: ILO.

Mitra, Iman, Ranabir Samaddar, and Samita Sen. 2017. Accumulation in Post Colonial Capitalism. Singapore: Springer.

Morris, Sebastian. 2014. A Comparative Analysis of Gujarat's Economic Growth. In Growth or Development: Which Way is Gujarat Going?, ed. I. Hirway, A. Shah, and G. Shah. New Delhi: Oxford University Press.

National Commission on Labour. 2002. Report of the Second National Commission on Labour. Ministry of Labour. New Delhi: Government of India.

National Commission on Rural Labour. 1991. Report of the National Commission on Rural Labour. Ministry of Labour. New Delhi: Government of India.

NCEUS. 2007. Report on Conditions of Work and Promotion of Livelihoods in the Unorganised Sector. New Delhi: National Commission for Enterprises in the Unorganised Sector, Government Press

Papola, T.S., and Jesim Pais. 2007. Debate on Labour Market Reforms in India: A Case of Misplaced Focus. The Indian Journal of Labour Economics 50: 183-200.

Prasad, Archana. 2016. Adivasi Women, Agrarian Change and Forms of Labour in Neo-liberal India. Agrarian South: Journal of Political Economy 5(1): 20-49.

Prayas Centre for Labour Research and Action. 2009. Situational Analysis of Construction Labour Market of Ahmedabad City. Ahmedabad: Prayas CLRA.

Shah, Alpa and Jens Lerche. 2018. Tribe, Caste and Class-New Mechanisms of Exploitation and Oppression. In Ground Down by Growth: Tribe, Caste, Class and Inequality in Twenty First Century India, ed. Alpa Shah, Jens Lerche, Richard Axelby, Dalel Benbabaali, Brendan Donegan, Jayaseelan Raj and Vikramaditya Thakur, 1st ed, 1-31. New Delhi: Oxford University Press.

Sharma, Amrita, Santosh Poonia, Zainab Ali, and Rajiv Khandelwal. 2014. Their Own Country: A Profile of Labour Migration from Rajasthan. Udaipur: Aajeevika Bureau.

Sharma, Yogima. 2020. Centre Likely to Fast-Track Changes for Uniform Flexi Labour Laws. Economic Times, 25 May. https://economictimes.indiatimes.com/news/economy/policy/centre-foruniform-flexi-labour-laws/articleshow/75958644.cms?from=mdr. Accessed 11 Aug 2020.

Shyam Sundar, K. R. 2014. The Myth of Inspector-Raj in India. Economic and Political Weekly 49(42).

Shyam Sundar, K. R. and Rahul Sapkal. 2020. Changes to Labour Laws by State Governments Will Lead to Anarchy in the Labour Market. Economic and Political Weekly 55(23).

Sood, Atul. 2012. Poverty Amidst Prosperity: Essays on the Trajectory of Development in Gujarat. New Delhi: Aakar Books.

Sood, Atul and Paaritosh Nath. 2020. Labour Law Changes: Innocuous Mistakes or Sleight of Hand?. Economic and Political Weekly 55(22).

Srivastava, Ravi. 2012. Internal Migrants and Social Protection in India: The Missing Link. National Workshop on Internal Migration and Human Development in India. Workshop Compendium Vol. II, pp. 166-193. New Delhi: UNESCO \& UNICEF.

Subramanian, Reetika. 2018. Synthetic Fabric, Authentic Despair. People's Archive of Rural India, 12 June. https://ruralindiaonline.org/articles/synthetic-fabric-authentic-despair/. Accessed 11 Aug 2020.

Thamarajakshi, R. 2005. “Overview”, Informal Economy: The Growing Challenge for Labour Administration. New Delhi: ILO.

Thomas, Cenny and Nivedita Jayaram. 2020. Pandemic Crisis: Migrant Home-Based Women Workers Work 8 Hours/Day For Rs 10-15. Indiaspend, 23 July. https://www.indiaspend.com/pandemiccrisis-migrant-home-based-women-workers-work-8-hours-day-for-rs-10-15/. Accessed 11 Aug 2020.

Tumbe, Chinmay. 2019. A Million Migrations: Journeys in Search of Jobs. LiveMint, 17 January. https ://www.livemint.com/Politics/8WPPsZygqR7Mu6e3Fgy55N/A-million-migrations-Journeys-insearch-of-jobs.html. Accessed 11 Aug 2020. 
Umarji, Vinay. 2020. After UP, Gujarat Offers 1,200-Day Labour Law Exemptions for New Industrial Investments. The Wire. https://thewire.in/economy/gujarat-labour-law-exemption-new-industries -covid-19. Accessed 11 Aug 2020.

Vietnam Law and Legal Forum. 2015. New Social Insurance Law Offers More Benefits to Employees. Vietnam Law and Legal Forum, 28 September. https://vietnamlawmagazine.vn/new-social-insur ance-law-offers-more-benefits-to-employees-4995.html. Accessed 11 Aug 2020.

Williamson, John. 2002. The Washington Consensus and Beyond. Economic and Political Weekly 37(15): 1475-1481.

Publisher's Note Springer Nature remains neutral with regard to jurisdictional claims in published maps and institutional affiliations. 